\title{
UNIVERSITY STUDENTS AS RECIPIENTS OF AND CONTRIBUTORS TO INFORMATION ON CLIMATE CHANGE: INSIGHTS FROM SOUTH AFRICA AND IMPLICATIONS FOR WELL-BEING
}

\author{
Mona Betour El Zoghbi ${ }^{1}$, Walid El Ansari² \\ ${ }^{1}$ General Contracting and Quarries Corporation (GCQC), Zgharta, Lebanon \\ ${ }^{2}$ Faculty of Applied Sciences, University of Gloucestershire, Gloucester, United Kingdom
}

\begin{abstract}
SUMMARY
Aims: This study aimed to enhance the in-depth understanding of the contextual dimensions that shape the relationships between climate change communication approach and youth well-being. The study focused on university students who constitute the key stakeholders and future decision-makers and leaders for managing the long-term climate risks.

Methods: A total of 10 focus group interviews were conducted with 117 undergraduate and graduate South African university students from over 12 universities located in different provinces of South Africa. In addition, another 16 interviews were also undertaken with university students, 10 interviews with key experts, and 3 youth national events were attended as participant-observation.

Results: As recipients of information on climate change, students' well-being was negatively affected by the media's pessimism of communicating risks and the inadequate or restricted networking of communicating solutions and strategies. As contributors to information on climate change, students faced key barriers to their efficacy and agency that entailed socio-cultural inequalities (e.g. race and language) and a lack of formal forums for community recognition, policy consultation and collaboration. In addition, for some students (e.g. journalism students), the lack of sufficient knowledge and skills on climate change and sustainability issues limited their ability to effectively communicate these issues to their audience.

Conclusions: Platforms for interactive and reflective discussions, access to innovative technologies and social media, and opportunities for multi-stakeholder partnerships are keys to the success of youth-targeted and youth-initiated communication on climate change.
\end{abstract}

Key words: climate change, communication, youth, well-being, cultural context, university students

Address for correspondence: M. Betour El Zoghbi, General Contracting and Quarries Corporation (GCQC), Zgharta Main Road, Zgharta, JA Bldg., Lebanon. E-mail: monazoghbi@gmail.com

\section{INTRODUCTION}

The latest Intergovernmental Panel on Climate Change Report (1) projected that climate change could cause severe global impacts that threaten future prospects for security, health and development. Particularly for young people, the global climate change crisis poses grave challenges with wide-ranging impacts across all sectors of life, and short and long-term risks to health and prosperity (2).

Young people will face the climate challenges in their future families, as members of the future workforce and communities. They will need to deal with climate impacts such as extreme weather events and rising temperatures which are anticipated to become more extreme and frequent (2). The long-term implications of climate change could extend beyond the immediate physical impacts to include many dimensions of well-being (e.g., youth's emotional and mental health, social inclusion and participation, academic and professional functioning and quality of life) (3).

University students' quality of life and well-being can be particularly influenced by the type of information they receive on climate change which strongly shapes their sense of efficacy and agency to influence changes within their communities (4). Studies have shown that the communication approach on climate change can have a major influence on people's understandings, opinions and responses to its risks (5).

Particularly in today's globalized world, university students are avid technology users who are being influenced by viewpoints from both advocates and skeptics on climate change (6). At the same time, diverse education and learning opportunities can render university students a valuable source of information and action on climate change (7). The critical role that university students can play as both recipients and contributors of information on climate change implies the need for enhancing their understanding of such dynamics in particular contexts.

Nevertheless, the literature reveals certain gaps, as in-depth and contextual insights into the personal experiences of university students with climate change communication remain under-researched $(8,9)$. MacDonald et al. (10) highlighted that: "globally, youth voices and their experiences, observations, and perceptions about climatic and environmental change and variability are relatively absent in the published literature to date". Some studies focused on public attitudes without considering the other spectrum of climate change communication, namely when the people are themselves the informants or contributors rather than receivers of such information $(5,11)$. Geographical gaps 
also seem to exist: scholarly research on climate change communication and public knowledge has largely been focused on the developed world, whilst fewer studies have explored the most vulnerable continent, Africa (12). The current study bridges these knowledge gaps to enhance the understanding of the experiences of university students when they are recipients and contributors of information on climate change. Figure 1 illustrates the knowledge gaps that guided the conceptual framework for this study.

This study explored the experiences of university students as: 1) recipients; and, 2) informants within the spectrum of climate change communication. It sought to enhance the understanding of two sides of the coin: 1) students' interpretations and insights on the influence of the approach and content of climate change communication that they receive from various media and academic sources; and, 2) students' influence of their particular academic and socio-cultural setting on their ability and efficacy to convey such information to their communities. The study was conducted among university students across South Africa in 2011. It sought to generate in-depth insights through the personal experiences of university students from different personal and academic backgrounds. The specific objectives were to:

- explore the influence of the type of communication received on climate change on students' understandings, concerns and responses (students as recipients of information);

- explore the contextual barriers and opportunities for students when they are informing their communities on climate change risks and responses (students as contributors to information);

- generate recommendations to inform the media, academic institutions, youth organizations and policy-makers on strategies to empower university students as recipients of and contributors to information on climate change.

\section{Settings: South Africa}

South Africa is challenged with widespread social and economic inequalities and complex governance and institutional problems. The country's youth will need to manage these challenges as they face the rising risks of climate change (13). Young South Africans need to communicate the climate change risks and potential solutions to their communities whilst proposing alterna-

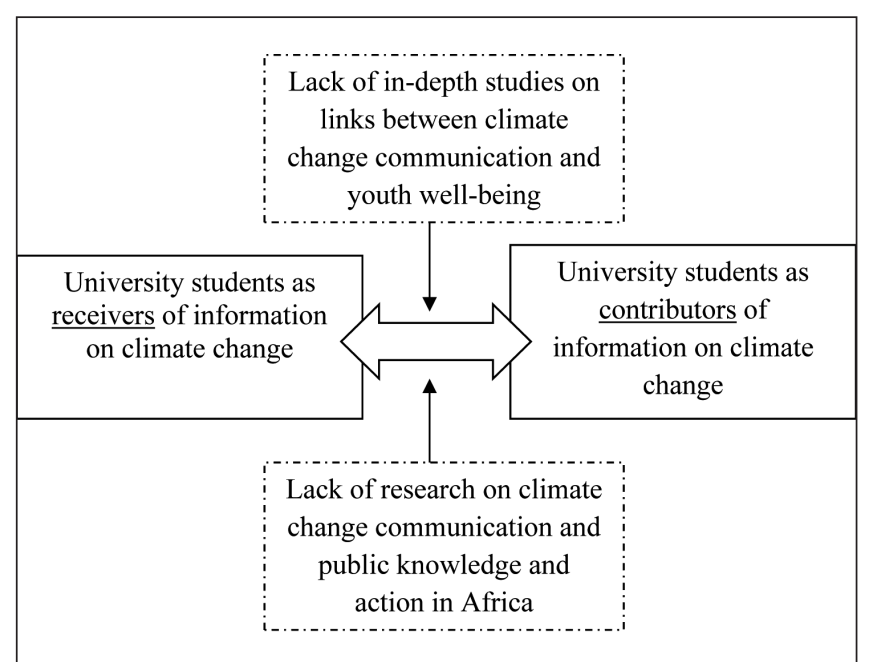

Fig. 1. Knowledge gaps guiding the conceptual framework for the study. tives for securing and sustaining livelihoods that are dependent on natural resources (12). The complexity of such challenges and their attending opportunities that face university students in South Africa reflect the importance of this study to enhance our understanding of their experiences with climate change communication and the implications for their well-being.

\section{MATERIALS AND METHODS}

This qualitative study applied a critical interpretivist research approach. It sought to understand young people's experiences through their own accounts and interactions in a reflective and dialogic setting. The study also focused on understanding the contextual setting in which such interactions and experiences take place through exploring the environmental, socio-cultural, academic and political contexts of South Africa. Our aim was to achieve a diversity of participant profiles and their experiences with the research themes. We maintained research ethics by ensuring privacy, confidentiality and anonymity (14).

\section{Study Design}

The study was approved by the Research Ethics Committeee of the University of Gloucestershire, United Kingdom. The first author spent 3 months in South Africa (July-September 2011) to undertake the fieldwork using focus groups, interviews and participant-observation. A total of 10 focus groups comprised 117 students from over 12 different universities in different regions across South Africa. The study undertook a single-category design of focus groups with one type of participants who were South African university students (15). Semi-structured interviews were also undertaken with 16 university students from different academic fields and institutions. The interviews were conducted face-to-face with open-ended questions in order to generate in-depth data on the participants' experiences and perspectives (14). In addition, 20 interviews were conducted with key informants /experts in various fields (e.g., government officers, managers and researchers in academic institutions, coordinators of youth or environmental organizations) to enhance the understanding of the South African setting. Moreover, using participant-observation, the first author attended 3 events in South Africa (a southern African regional media conference, a national sustainability conference, and a youth leadership forum). Finally, the author kept a research diary to document the analytical process of critical thinking of the emerging data and themes as she was undertaking the data collection and analysis (14). The criteria for inclusion in the study were intentionally kept minimal and included that participants needed to be South African university students, preferably of different academic disciplines, aged 18-30, undergraduates and graduates, and both males and females.

\section{Qualitative Data Analysis}

We used inductive analysis to generate the main codes and categories from the data itself rather than pre-assigned categories. We organized the data through organizational, substantive and theoretical codes (16). The analysis interpreted the identified themes by locating them back within participants' personal experi- 
ences and socio-political environment. Collectively, this analytical approach contributed in-depth and contextual insights into the personal interpretations and experiences of university students in South Africa on climate change communication.

\section{Quality and Validity of the Study}

The quality and validity of the study were maintained through triangulation of research findings, prolonged engagement in the field and researcher reflexivity. First, we triangulated the findings using several data collection methods that included focus groups (for interactive discussions amongst diverse participants), interviews (for in-depth understanding of participants' experiences) and participant-observation (for observing and documenting first-hand the experiences and interactions of participants in their contextual setting) (14). Second, the prolonged engagement in the field ( 3 months) helped build trust and rapport with participants, and enhanced the understanding of the local culture. Third, we applied researcher reflexivity throughout the data collection and analysis process to manage personal perspectives that might influence the discussions with participants, or early assumptions regarding the meanings that the data might signify (14).

\section{RESULTS AND DISCUSSION}

In terms of the study population, the research participants comprised a wide range of South African university students aged 18-30. Participants comprised undergraduate and graduate students from different socio-demographic backgrounds, regions, academic disciplines, and universities (Table 1).
The study findings captured important insights into the influence of climate change communication on the experiences and well-being of university students in South Africa. These findings are categorized under two main themes: the first theme addressed youth as recipients of communication or information on climate change; the second theme addressed youth as contributors to information on climate change. Figure 2 summarizes the key findings and presents selected quotes from the participants.

\section{Theme 1: University Students as Recipients of Infor- mation on Climate Change}

The study findings highlighted the influence of the climate change information and education provided through the media on the participants' knowledge and emotions on the topic. The five sub-themes that emerged are discussed below and included: the negativity of the communication approach, language barriers, poor organization of environmental events, lack of knowledge among journalism students for reporting on climate change, and the role of media in connecting various local initiatives.

\section{Negativity/Pessimism of Communication Approach}

The majority of participants indicated that the negativity and complexity in the communication of climate change by experts and through media sources leads to disengagement from this global crisis at a personal level. One focus group (FG) participant questioned the pessimistic and threatening messages that are often portrayed in the media which generate feelings of fear: "In few decades, if we carry on the rate we're going, things like that (the disasters showed in the media) will happen."

Table 1. Participants' profile - focus groups in South Africa

\begin{tabular}{|c|c|c|c|c|c|}
\hline $\begin{array}{l}\text { Focus group (FG) } \\
\text { location }\end{array}$ & $\begin{array}{l}\text { No. of } \\
\text { participants }\end{array}$ & Age range & $\begin{array}{l}\text { Female (F) } \\
\text { Male (M) }\end{array}$ & Academic disciplines & Academic level \\
\hline FG 1 Grahamstown & 18 & $19-25$ & $\begin{array}{l}13 \mathrm{~F} \\
5 \mathrm{M}\end{array}$ & Journalism & Undergraduates \\
\hline FG 2 Grahamstown & 5 & $20-23$ & $\begin{array}{l}2 \mathrm{~F} \\
3 \mathrm{M}\end{array}$ & $\begin{array}{l}\text { Law, Accounting, Taxing, Economics, Politics, } \\
\text { Finance }\end{array}$ & $\begin{array}{l}\text { Undergraduate: } 4 \\
\text { Graduate: } 1\end{array}$ \\
\hline FG 3 Grahamstown & 13 & $18-21$ & $\begin{array}{l}9 \mathrm{~F} \\
4 \mathrm{M}\end{array}$ & $\begin{array}{l}\text { Environmental Sciences, Landscape Manage- } \\
\text { ment, Sociology, Journalism, Architecture, Graphic } \\
\text { Design, Medicine }\end{array}$ & $\begin{array}{l}\text { Undergraduate: } 12 \\
\text { Graduate: } 1\end{array}$ \\
\hline FG 4 Grahamstown & 4 & $18-20$ & $4 \mathrm{M}$ & Economics, Math, Ichthyology, Philosophy & Undergraduates \\
\hline FG 5 Port Elizabeth & 20 & $18-24$ & $\begin{array}{l}13 \mathrm{~F} \\
7 \mathrm{M}\end{array}$ & $\begin{array}{l}\text { Architecture, Accounting, Chemistry, Linguistics, } \\
\text { Engineering, Law, Economics, Environmental } \\
\text { Health, Technology IT, Social Work }\end{array}$ & $\begin{array}{l}\text { Undergraduate: } 18 \\
\text { Graduate: } 2\end{array}$ \\
\hline FG 6 Durban & 12 & $18-22$ & $\begin{array}{l}5 \mathrm{~F} \\
7 \mathrm{M}\end{array}$ & $\begin{array}{l}\text { Forest Fires Training Group, Part of Poverty } \\
\text { Alleviation Programme }\end{array}$ & High-school students* \\
\hline FG 7 Durban & 11 & $22-26$ & $\begin{array}{l}6 \mathrm{~F} \\
5 \mathrm{M}\end{array}$ & Environmental Management, Landscape Design & $\begin{array}{l}\text { Undergraduate: } 8 \\
\text { Graduate: } 3\end{array}$ \\
\hline FG 8 Eastern Cape & 25 & $20-24$ & $\begin{array}{l}19 \mathrm{~F} \\
6 \mathrm{M}\end{array}$ & Geology, Environmental Sciences & Undergraduates \\
\hline FG 9 Durban & 3 & $20-21$ & $\begin{array}{l}2 \mathrm{~F} \\
1 \mathrm{M}\end{array}$ & $\begin{array}{l}\text { Eco-Tourism Management, Sports Management, } \\
\text { Social Sciences }\end{array}$ & Undergraduates \\
\hline FG 10 Stellenbosch & 6 & $19-20$ & $\begin{array}{l}5 \mathrm{~F} \\
1 \mathrm{M}\end{array}$ & $\begin{array}{l}\text { Accounting, Earth Sciences, Environmental } \\
\text { Studies, Media Studies }\end{array}$ & Undergraduates \\
\hline
\end{tabular}

${ }^{*}$ The first author took an opportunity to explore the themes with high school students who were part of a poverty-alleviation programme in order to enhance understanding of the country's contextual setting and the diversity of youth backgrounds in South Africa. 


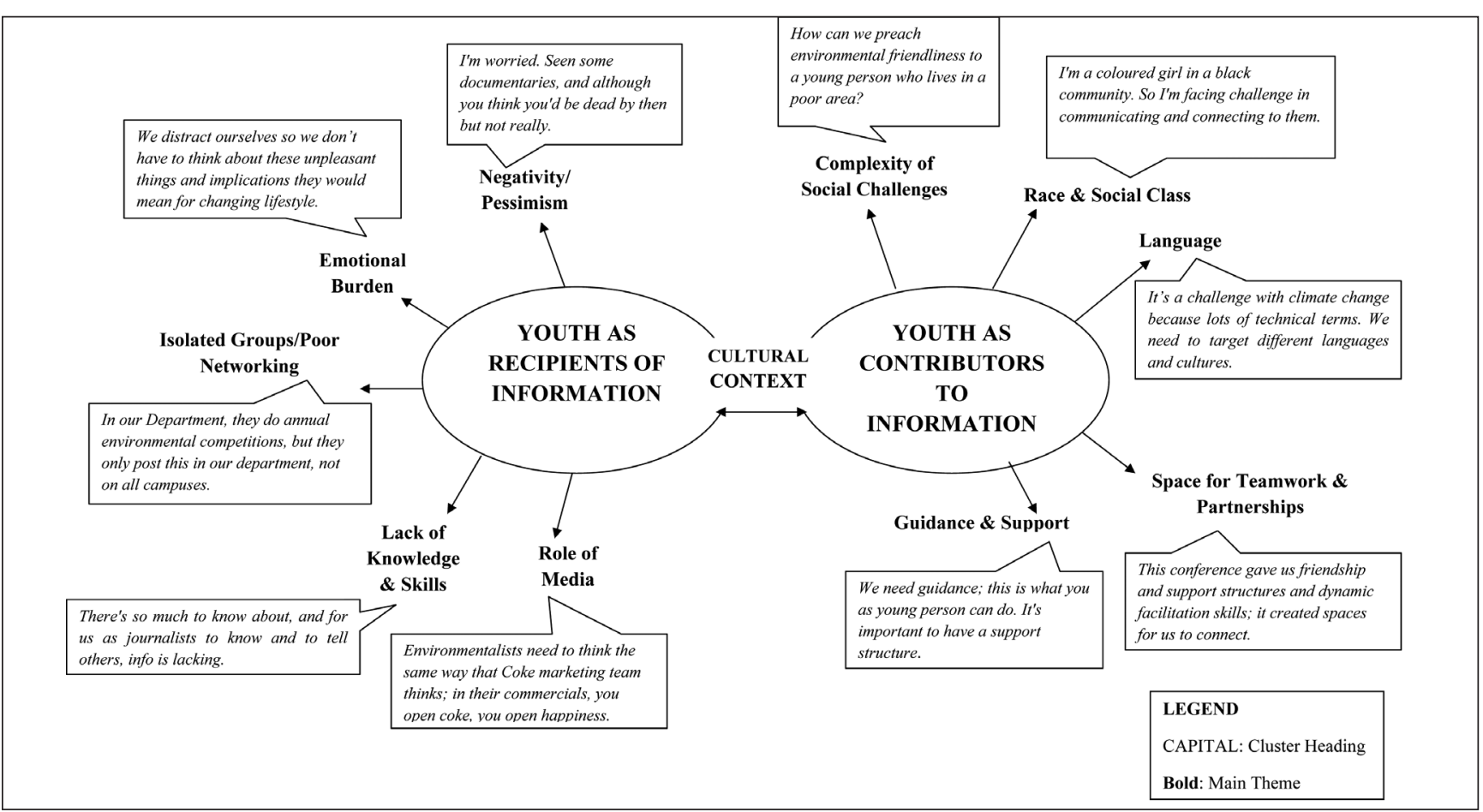

Fig. 2. Summary of key findings and sample quotes.

A participant in a youth sustainability forum criticized the negative climate messages that overwhelm the public and force them to overlook such realities to avoid emotional disturbances to their lives: "Climate change is like the new AIDS, people don't want to know or hear about it, fatigue."

A student interviewee further pointed out the ambiguous and blaming style of communication of most climate scientists and communicators: "Humans always blamed, this is the usual message that is conveyed. Image portrayed: you are the problem...All know there is climate change but don 't understand what it really means."

Other researchers have reported the abstract and technical communication approach on climate change as an important reason behind young people's disconnection from this global crisis (17). In line with our findings, such emotional and mental reactions to climate change communication can generate feelings of hopelessness, despair and disempowerment which can impede active and interactive engagement.

Research suggests that people sometimes use emotionalresponse strategies, such as denial or externalization of responsibility, to handle climate change psychologically (18). Such strategies are perceived to cause people to distance themselves from the climate crisis and consider themselves unable to help or control the situation, which can increase stress and lower psychological well-being.

\section{Language Barriers}

Some participants highlighted the language barriers in current communication approaches on climate change, where the complexity and jargon of the information provided can lead to disengagement at a personal level. An interviewee indicated that: "Info at the environment club lecture was too much, needs dictionary to understand. It should be in our own language. English is too big sometimes for us, they bombard us with big English words. How will I understand these complex terms? I will become excluded from the talk."

An FG participant described the challenges of communicating climate change information across the diversity of cultures and communities in South Africa: "It needs to be clear and simple, pictures can communicate. In rural areas, if it's in their language they relate more to it. But it's difficult to translate to different languages, especially with climate change because lots of technical terms. I had to translate questions to Zulu, some words don 't even exist."

Researchers have emphasized the tailoring of climate change information to local audience groups through using relevant language and focusing on local impacts to people's health and quality of life (4). This is congruent with our participants' discussions of the need for adequate media reports and public awareness campaigns on climate change that target the local community context.

\section{Poor Organization and Promotion of Environmental Events On-Campus}

Several participants reported the poor communication of spaces and platforms for participating in environmental events on campus. An FG participant shared her personal experiences: "If you're studying commerce or something outside the environment field, you don't get to know about these events until you bump into someone environmentalist."

Likewise, an interviewee who is interested in environmental activities explained that the difficulty is in finding out about such events that are usually poorly networked across the university: "Events usually within the environment group but they don't extend. Need to partner with other societies. But these societies don't often agree because they don't see the relevance or not interested...Problem is that it should not be a 'group' thing; they isolate. I focus on my environment group and you focus on yours; that's the problem in South Africa." 
These findings are in agreement with similar themes that have emerged in other studies, such as the review of several case studies of youth participation around the world by Golombek, and the study by Jensen et al. on the involvement of young Europeans in national environmental and health plans $(19,20)$. These authors recommended that youth initiatives not only be targeted at youth as audience, but also should aim to meaningfully engage them in project planning and implementation.

\section{Lack of Knowledge and Skills for Reporting on Climate Change}

Through data collected by participant-observation, numerous participants who were student journalists expressed their lack of competencies for adequately covering the climate change stories and influencing their communities. One participant criticized the complexity and uncertainty of climate change science and the difficulty of communicating credible information to their audience when they themselves, as journalists, lack proper understanding of the global debates: "Climate change topic needs to be broken down, it's like an elephant to swallow. I as a journalist need to understand the science behind climate change before I can research the story or talk to people."

Another participant discussed the challenges of reporting incomplete or inaccurate information on climate change and the important role of the media in mobilizing awareness and action:

"We are not equipped to write about it as a real problem. We need to understand it. Our role depends on how much we know and how much story we sell. To make it sound good, we need to know about it... Not all media people realize they need to be activists, need to instigate, not just report."

Another journalism student stressed the need for developing competences and guidance of such students on adequate ways of gathering facts on climate change from multiple data sources and from trusted informants in the field: "I've never reported on climate change. Used to cover politics and crime; now asked to cover COP17 (Conference of the Parties on Climate Change). How do we report on COP17 if we don't understand climate change? We need training, teaching on it. It's daunting to have to cover all this complex issue without having basics. How do we know if a study is legitimate? We struggle to get those experts, to get alternative aspects."

Several of our key informant interviewees expressed the importance of providing adequate education and training to future journalists for reporting climate change. Numerous scholars and institutions are also stressing the need for developing new forms of education and learning that build youth capacity on global issues $(13,21)$. The provision of opportunities for learning about complex world problems in a practical and solution-focused approach could help students such as our study participants to understand and communicate more effectively the challenges and opportunities of climate change (22).

\section{Importance of Media: Covering and Connecting Local Initiatives}

Many FG participants emphasized the important role of the media not only as an informative medium on climate change but also as a networking platform for connecting various stakeholders and organizations working on these themes: "I am a recent journalism graduate. Now working for an environmental newspaper. We try to write positive stories so we can use media for good, for raising awareness in society. What our nation reads determines how they think and behave...It's also important that we help with networking, green initiatives need to be linked and collaborating."

Of particular importance in the current literature is the role of 'new' media (e.g., online social networks and websites) in connecting youth and sharing exciting endeavour taking place across the globe (6). The connections created by such new media can enhance the efficacy and agency of university students to collaborate with other stakeholders locally and globally on climate change initiatives.

The second major theme that emerged from the data related to the participants' experiences as contributors to information and action on climate change, as further elaborated below.

\section{Theme 2: University Students as Communicators on Climate Change}

The study findings highlighted the contextual factors that influence the effectiveness of student initiatives in raising public awareness on climate change. The key themes captured the burdens of social challenges and the socio-cultural barriers such as prejudice triggered through racial and inter-generational complexities, and the opportunities created through teamwork, partnerships and technology.

\section{Complexity of Socio-Cultural Challenges: Poverty, Race and Generation-Gap}

Numerous participants discussed the social challenges to enable changes in their communities towards more sustainable lifestyles. Such social challenges included widespread poverty, lack of education and unemployment. One FG participant articulated these challenges: "In South Africa we're still struggling with our historical challenges, and environmentally-friendly products are still very expensive and technological. How do people afford green products? Environmental living is very expensive. If you ask the poor not to cut trees, how do they afford solar panels? Even if there's the knowledge, there so many other issues to deal with before addressing that."

Other participants discussed barriers to communication at the community level, indicating that young people from diverse racial groups can feel less empowered and influential to address or advise their communities. A participant in Event 2 expressed his inability to gain the trust of the elders in his community when communicating the risks of climate change and the possibilities for alternative lifestyles: "Our wisdom is subjected to opinions of elders; I come from traditional community; difficult to change elders' minds. They say we have been doing this for so long...If you try talking to adults, they won't listen or respect you; makes you doubt yourself...Most of youth are questioning authority, that's what they (elders) are worried about."

Another Event 2 participant described the racial challenges mobilizing action on climate change: "In South Africa we shy away from racial things. But its fact that black people are very ignorant when it comes to environmental issues; it's not my thing it's a white man's thing." 
Several key informants that we interviewed also indicated that the social and political mistrust in South Africa has contributed to doubting self-efficacy and externalizing responsibility of action from the individual to the national, even international level. One informant further explained such cultural dynamics, indicating that: "These stereotypes of green issues, especially in South Africa, can severely disrupt real contributions and involvement of different social groups...It's partly related to our history of social struggles and the lack of trust in each other...things we are trying to work on now as different communities. I think the best way is to work as communities together to restore that bond."

\section{Importance of Teamwork and Partnerships}

Many participants in the events attended by the first author emphasized the importance of teamwork for enhancing confidence and sense of empowerment to contribute to changes in their communities. As articulated by one participant: "I wasn't expecting so many black people. I thought all would be whites. I feel empowered."

Other participants at the event indicated that such platforms for collective dialogue and action gave them confidence and a shared vision for change: "Being part of this forum changed my mindset... Listening to each other's visions, we realized we are all same people, want same things. We all have passion to make change in the environment."

"A lot of warmth around me; a lot of people with the same vision that I have. We can pull together as a group. I saw the waste in Johannesburg, not like where I come from in Northern Cape. Also there we walk everywhere. Here in Johannesburg I see it's very disorganized. Can I really contribute to changing the world? I felt confused. Didn't feel motivated. Then I come here and I get excited again."

Research also indicates that people may respond to climate threats with social engagement, which can enhance their sense of empowerment and well-being (7). Providing spaces for dialogue and partnerships can enhance university students' sense of belonging and connection to institutions in order to contribute to challenges such as climate change.

\section{Importance of Guided Leadership}

The study captured data indicating the need for developing young people's leadership skills. This was mostly captured through participant-observation during events in which young South Africans discussed the support and guidance they needed for enhancing their initiatives. One participant indicated that: "We have great ideas, we feel there is something wrong and we see the need to do something. My question is: How do we go about to solve this? How do we get our communities to listen to what we have to say and act on that? I expect set of skills from this forum and a broad viewpoint on which is best way to lecture traditional people about the environment, and how to balance the economic side of environmental issues." Another participant pointed out the importance of providing youth with formal platforms for consultation on global climate change debates, and the need for community recognition and appreciation for their actions: "We need to move away from youth vs adults. Give us a bigger role in making decisions. It's our future on the line and we need to work
together...In COP15 there's no understanding of what youth want. I want to learn how to change the mindset. We need guidance; this is what you as young person can do. It's important to have a support structure... We need 'I appreciate what you're doing; carry on'. We don't have a pat on the shoulder."

These participants articulated the importance of provision of adequate social and political spaces for enhancing their competencies and skills, and their recognition as a representational group with the power to make an impact.

\section{Importance of Humour and Positivity in Communicat- ing Climate Change}

The study captured considerable data that suggested the importance of youth-targeted initiatives that appeal to a wide range of students. Two FG participants' experiences illustrated this:

"Make green cool. People want to do it if it's enjoyable and if they can see they're making a difference; it will make them feel good if they see they've helped and made a difference."

"We started something like a green student police on campus. It's about being visible and making it fun. Students know we are there; to not lose power and momentum of what we are doing."

Other participants suggested engaging university students from the beginning of initiatives rather than merely asking for their opinions and attendance: "Get students involved in preparation of events, so they wouldn't feel isolated and you get them interested."

Some participants described projects that appeal to, and encourage participation from a wide variety of student backgrounds and academic disciplines: "Last year we did door-to-door campaigns in each student residence to encourage recycling. We are doing this year a green fashion show, with designers from all over South Africa... creating awareness on the environment... and designers create garments from recycled material; this brings in more students from different fields."

In resonance with our study findings, youth programmes that generate inter-cultural and social interactions have been found to enhance self-efficacy, social competence and sense of civic responsibility to work on social and environmental issues (23). Communicating climate change science inter-personally and innovatively could appeal more to university students than one-way communication such as flyers, posters or lectures which might only convey negative messages.

\section{Empowering Role of Technology: Greater Access to Information and Initiatives}

The majority of our participants discussed the empowering potentials of technology and new media for gaining access to information and networking with others over shared environmental causes. Two event participants indicated that: "There's advance in ways of communicating and it's empowering. With digital media, anyone can access, can communicate their concerns without barriers to entry and can exchange ideas with like-minded people."

"Communities can bridge gaps through internet. Access to mobile internet in South Africa is a platform for youth to access information, lets them know what is happening nationally but also globally. It bridges the identity divide...They have a space to express and there are people who want to listen."

Most participants also noted that new technologies and social media are important bridges between local and global issues, es- 
pecially for university students in developing countries who strive for new information and voice. Several of our key informants in South Africa similarly emphasized the importance of widespread access to new media and internet technologies in empowering university students in South Africa to share their stories and initiatives. This could boost the confidence, mental health and sense of belonging of students in Africa, as scholars have often identified civic action and engagement as positive contributors to well-being (23).

Collectively, our findings provide novel insights into the personal experiences of university students in South Africa as recipients and contributors of information on climate change. Yet this study has limitations. The differences in the size and/ or profile of participants across each focus group was a natural result of voluntary participation and could influence the type of data generated (14). The diversity and depth of insights generated through our study might limit the ability to make generalizations of our findings across the wide spectrum of university students in South Africa. However, such diversity meets the aims of our study for profound and contextual understanding of the experiences and perspectives of different participants.

\section{Implications for Policy, Practice and Research}

This study provided valuable insight into the dynamic experiences of university students as recipients and contributors of information on climate change. Important implications for policy and practice entail the following:

\section{University Students as Recipients of Information on Climate Change}

The media coverage on climate change and sustainability issues could be improved through creative and humorous approaches that can be planned and developed in collaboration with young people. It is suggested that emotional, ethical and informative components are interwoven, rather than relying solely on negative and fear-inducing messages which might reduce perceived efficacy.

Schools and universities could incorporate social media and new technologies for simplifying the science of climate change. It is also recommended that universities establish platforms for students to collaborate on designing and implementing communication initiatives on climate change that are tailored to meet the specific literacy levels and needs of local communities.

\section{University Students as Contributors of Information on Climate Change}

Universities could integrate environmental education and training into the courses of journalism students to enhance their understandings of these issues and their ability to influence their audience. Upcoming international environmental conferences (e.g., the upcoming Conference of the Parties on Climate Change, and the UNESCO World Conference on Education for Sustainable Development 2014) could also provide fellowships for young journalism students to build their capacities in reporting such important events.

Greater collaboration is recommended between youth-initiated and led sustainability organizations and their larger national and international counterparts. Partnerships and guided leadership would enhance young people's leadership skills to better organize themselves, identify their target audience and communicate more effectively.

Local governments and municipalities could establish formal consultation platforms such as youth councils for university students to formalize their contributions in shaping public policy on climate change communication.

Future research could explore innovation in academic education for enhancing university students' competencies and leadership skills on climate change communication and action. Research should also examine the ways in which power differentials in a community, such as social class, gender, culture, language, and educational status can shape the efficacy and agency of university students for conveying information on climate change to their local communities.

\section{CONCLUSION}

University students, whether living and studying in Africa, Europe or elsewhere in the world, need to be valued as both recipients and contributors of information on climate change. They need to be provided with adequate knowledge and skills to enhance their efficacy and sense of well-being for contributing to action within their own communities. Feelings of anxiety and distress, such as those expressed by some of our study participants, could be overcome through spaces that generate hope. University students can feel more hopeful about their future if they are provided with opportunities for meaningful engagement in addressing global problems such as climate change through realistic goals and solution-focused strategies (23). Hence, within the spectrum of climate change communication, it is essential that university students and other societal stakeholders share information on climate change, acting simultaneously as recipients and contributors of such information at a time when one-way communication is generating more despair than hope.

\section{Acknowledgement}

The authors thank all the Universities and university students who participated in this study. We also thank the experts and event organizers who supported the fieldwork; and Professor D. Tilbury for her inputs to this research.

\section{Conflict of Interest}

None declared

\section{REFERENCES}

1. Solomon S, Qin D, Manning M, Chen Z, Marquis M, Averyt KB, et al., editors. Climate change 2007: the physical science basis. Contribution of working group I to the fourth assessment report of the intergovernmental panel on climate change. Cambridge: Cambridge University Press; 2007.

2. United Nations Framework Convention on Climate Change (UNFCCC). Climate change: impacts, vulnerabilities and adaptation in developing countries. Bonn: UNFCCC; 2007.

3. Carlisle S, Hanlon P. "Well-being" as a focus for public health? A critique and defence. Crit Public Health. 2008;18(3):263-70.

4. O'Neill S, Nicholson-Cole S. "Fear Won't Do It" Promoting positive engagement with climate change through visual and iconic representations. Sci Commun. 2009 Mar;30(3):355-79. 
5. Leiserowitz A, Maibach E, Roser-Renouf C. Climate change in the American mind: Americans' global warming beliefs and attitudes in January 2010. New Haven, CT (US): Yale University and George Mason University; 2010.

6. O'Neill S, Boykoff M. The Role of new media in engaging the public with climate change. In: Whitmarsh L, O’Neill SJ, Lorenzoni I, editors. Engaging the public with climate change: behaviour change and communication. London: Earthscan; 2011. p. 233-51.

7. Thompson E, Arsalan L. Preparing youth for leadership roles in changing environments: the Jordan experience. Child Youth Environ. 2007;17(3):49-65.

8. Bostrom A, O'Connor RE, Böhm G, Hanss D, Bodi O, Ekström F, et al. Causal thinking and support for climate change policies: International survey findings. Glob Environ Change. 2012;22(1):210-22.

9. Moser S, Berzonsky CL. There must be more: communication to close the cultural divide. In: O'Brien K, Selboe E, editors. The adaptive challenge of climate change. Cambridge: Cambridge University Press; 2014.

10. MacDonald JP, Harper SL, Willox AC, Edge VL; Rigolet Inuit Community Government. A necessary voice: climate change and lived experiences of youth in Rigolet, Nunatsiavut, Canada. Glob Environ Change. 2013;23(1):360-71.

11. Rabe B, Borick C. Climate change and American public opinion: the national and state perspectives. Virginia (US): Miller Centre of Public Affairs; 2008.

12. Reid P, Vogel C. Living and responding to multiple stressors in South Africa-Glimpses from KwaZulu-Natal. Glob Environ Change. 2006;16(2):195-206.

13. Lotz-Sisitka H. Insights from an environmental education research programme in South Africa. In: Cooper L, Walters S, editors. Learning/ work: turning work and lifelong learning inside out. CapeTown, South Africa: Human Sciences Research Council; 2009. p. 351-63.
14. Marshall C, Rossman G. Designing qualitative research. 5th ed. Thousand Oaks: SAGE Publications; 2011.

15. Krueger, R, Casey, M. Focus groups: a practical guide for applied research. 4th ed. Thousand Oaks: SAGE Publications; 2009.

16. Elo S, Kyngas, H. The qualitative content analysis process. J Adv Nurs. 2008 Apr;62(1):107-15.

17. Hulme M. Why we disagree about climate change: understanding controversy, inaction and opportunity. Cambridge: Cambridge University Press; 2009.

18. Stoll-Kleeman S, O'Riordan T, Jaeger CC. The psychology of denial concerning climate mitigation measures: evidence from Swiss focus groups. Glob Environ Change. 2001;11(2):107-17.

19. Golombek $\mathrm{S}$. What works in youth participation: case studies from around the world. 'What Works' Series. Baltimore, MD (US): International Youth Foundation; 2002.

20. Jensen BB, Simovska V, Larsen N, Holm LG. Young people want to be part of the answer: young minds as an educational approach to involve schools and students in national environment and health action plans. Copenhagen: WHO Regional Office for Europe; 2005.

21. El Ansari W, Stibbe A. Public health and the environment: what skills for sustainability literacy - and why? Sustainability. 2009;1(3):425-40.

22. Tilbury D, Stevenson R, Fien J, Schreuder D, editors. Education and sustainability: responding to the global challenge. Gland: Commission on Education and Communication, IUCN; 2002.

23. Johnson LR, Johnson-Pynn JS, Sweeney SS, Williams CT. Youth civic action: going green, going global. EcoPsychology. 2009;1(2):75-84.

Received December 14, 2013 Accepted in revised form April 24, 2014 